\title{
The effect of slaughter weight on pig production efficiency
}

\author{
E. Pieterse" $\#$, L.P. Loots and J. Viljoen \\ ARC - ANPI, P Bag X2, Irene, 0062, South Africa \\ ${ }^{\#}$ Email: Elsje@idpi1.agric.za
}

\section{Introduction}

Growth rate in fast growing pigs peaks at approximately $90 \mathrm{~kg}$ live weight (Whittemore, 1993), but feed conversion gets worse with increasing live weight. When these responses are considered together with the production costs of a weaner pig, it is possible to determine an optimal slaughter weight. This slaughter weight will, amongst others, depend on growth rate, feed intake, feed conversion ratio, lean meat percentage, production costs of a weaner pig, stocking density, housing costs, feed costs and the price of pork. The aim of this study was to determine the effect of slaughter weight on the production efficiency of pigs of different sexes.

\section{Materials and Methods}

Gilts and castrates (96 per sex type) were used in the trial. Animals entered into the trial at an age of 11 weeks and approximately $18 \mathrm{~kg}$ live weight and were housed in a commercial type grower facility. Pigs were randomly allocated to six different slaughter periods. The first group was slaughtered when the average live weight of all the pigs per sex type reached $90 \mathrm{~kg}$. The remaining five groups were then slaughtered at weekly intervals. By using this design, a slaughter weight range of approximately 90 to $120 \mathrm{~kg}$ over a period of six weeks was obtained. Pigs received a commercial grower diet containing $18 \%$ crude protein $(\mathrm{CP}), 1.1 \%$ lysine and $14 \mathrm{MJ} / \mathrm{kg}$ until an average live weight of 60 and $90 \mathrm{~kg}$ was attained for castrates and gilts respectively. Thereafter a diet containing $16 \%$ crude protein, $0.9 \%$ lysine and $13.5 \mathrm{MJ} / \mathrm{kg}$ digestible energy was fed until slaughter. Animals and feed were weighed weekly. Average daily gain (ADG) and feed conversion ratios (FCR) were calculated for individual animals and slaughter groups respectively, and P2 fat depth was taken weekly using ultrasound from the time that the average live weight reached $60 \mathrm{~kg}$. Carcass classification was noted at slaughter and muscle $\mathrm{pH}$ determined 60 minutes $\left(\mathrm{pH}_{1}\right)$ and 24 hours $\left(\mathrm{pH}_{\mathrm{u}}\right)$ post mortem $(\mathrm{pm})$ for the determination of PSE and DFD characteristics respectively. The day following slaughter, loin samples (M. longissimus thoracis) were taken and eye muscle area was measured using a Video Image Analyser (VIA). Data were analysed using Genstat 5 release 3.2 (1993). ANOVA analyses were conducted on all parameters measured, and where there were significant sex $x$ treatment interactions further analyses were done using the Bonferonni pairwise comparison.

\section{Results and Discussion}

Table 1 Growth and carcass data of gilts and castrates at various slaughter weights

\begin{tabular}{|c|c|c|c|c|c|c|c|c|c|}
\hline Treatment & $\begin{array}{c}\text { Live } \\
\text { weight } \\
(\mathrm{kg})\end{array}$ & $\begin{array}{l}\text { ADG } \\
\text { (g/day) }\end{array}$ & FCR & $\begin{array}{c}\mathrm{pH} \\
1 \mathrm{~h} \mathrm{pm}\end{array}$ & $\begin{array}{c}\mathrm{pH} \\
24 \mathrm{~h} \mathrm{pm}\end{array}$ & $\begin{array}{c}\text { Fat } \\
\text { thickness } \\
(\mathrm{mm})\end{array}$ & $\%$ Lean & Muscle area & Class \\
\hline \multicolumn{10}{|l|}{ Gilts } \\
\hline Group 1 & $94 \pm 9$ & $878 \pm 103$ & $2.65^{\mathrm{a}}$ & $6.7 \pm 0.2$ & $5.5 \pm 0.1^{\mathrm{b}}$ & $9.3 \pm 1.0^{\mathrm{a}}$ & $71.6 \pm 0.6^{\mathrm{e}}$ & $41.7 \pm 3.9^{\mathrm{ab}}$ & $\mathrm{P}$ \\
\hline Group 2 & $98 \pm 5$ & $842 \pm 55$ & $2.70^{\mathrm{a}}$ & $6.4 \pm 0.4$ & $5.5 \pm 0.1^{b}$ & $12.7 \pm 2.0^{\mathrm{ab}}$ & $70.2 \pm 0.9^{\mathrm{de}}$ & $47.3 \pm 4.7^{\mathrm{bcd}}$ & $\mathrm{P}$ \\
\hline Group 3 & $105 \pm$ & $864 \pm 43$ & $2.89^{\mathrm{a}}$ & $6.5 \pm 0.4$ & $5.5 \pm 0.1^{b}$ & $13.0 \pm 2.2^{a b}$ & $70.5 \pm 1.2^{\mathrm{de}}$ & $52.9 \pm 4.0^{\text {cde }}$ & $\mathrm{P}$ \\
\hline Group 4 & $106 \pm 6$ & $812 \pm 60$ & $2.90^{\mathrm{a}}$ & $6.7 \pm 0.3$ & $5.4 \pm 0.1^{\mathrm{a}}$ & $14.6 \pm 3.0^{b c}$ & $69.7 \pm 1.5^{\mathrm{de}}$ & $54.7 \pm 6.3^{\mathrm{de}}$ & $\mathrm{P}$ \\
\hline Group 5 & $114 \pm 11$ & $832 \pm 88$ & $2.88^{\mathrm{a}}$ & $6.7 \pm 0.3$ & $5.5 \pm 0.1^{b}$ & $14.9 \pm 1.6^{b c}$ & $69.8 \pm 0.9^{\mathrm{de}}$ & $53.7 \pm 7.0^{\text {de }}$ & $\mathrm{P}$ \\
\hline Group 6 & $118 \pm 7$ & $816 \pm 74$ & $2.98^{\mathrm{a}}$ & $6.6 \pm 0.3$ & $5.6 \pm 0.1^{b}$ & $15.5 \pm 2.3^{\mathrm{bcd}}$ & $68.4 \pm 1.0^{\mathrm{cd}}$ & $55.8 \pm 3.8^{\mathrm{e}}$ & $\mathrm{O}$ \\
\hline \multicolumn{10}{|l|}{ Castrates } \\
\hline Group 1 & $91 \pm 5$ & $892 \pm 55$ & $3.31^{b}$ & $6.8 \pm 0.2$ & $5.9 \pm 0.1^{\mathrm{c}}$ & $20.4 \pm 4.5^{\mathrm{def}}$ & $65.9 \pm 2.1^{a b}$ & $34.4 \pm 4.1^{\mathrm{a}}$ & $\mathrm{R}$ \\
\hline Group 2 & $100 \pm 7$ & $931 \pm 89$ & $2.98^{b}$ & $6.7 \pm 0.3$ & $6.0 \pm 0.1^{\mathrm{c}}$ & $18.8 \pm 3.2^{\text {cde }}$ & $67.1 \pm 1.6^{b c}$ & $45.5 \pm 6.1^{b c}$ & $\mathrm{R}$ \\
\hline Group 3 & $105 \pm 8$ & $905 \pm 61$ & $3.06^{\mathrm{b}}$ & $6.7 \pm 0.2$ & $6.0 \pm 0.2^{\mathrm{cd}}$ & $22.9 \pm 3.1$ ef & $64.9 \pm 1.6^{\mathrm{ab}}$ & $42.0 \pm 4.3^{\mathrm{ab}}$ & $\mathrm{R}$ \\
\hline Group 4 & $108 \pm 8$ & $882 \pm 61$ & $3.10^{\mathrm{b}}$ & $6.7 \pm 0.2$ & $6.1 \pm 0.1^{\mathrm{de}}$ & $18.3 \pm 5.9^{\text {cde }}$ & $67.2 \pm 3.0^{b c}$ & $44.4 \pm 4.8^{b}$ & $\mathrm{R}$ \\
\hline Group 5 & $113 \pm 12$ & $866 \pm 110$ & $3.35^{\mathrm{b}}$ & $6.7 \pm 0.2$ & $6.2 \pm 0.1^{\mathrm{e}}$ & $24.0 \pm 5.0^{f}$ & $64.5 \pm 2.5^{a}$ & $42.1 \pm 5.2^{b}$ & $\mathrm{C}$ \\
\hline Group 6 & $117 \pm 8$ & $848 \pm 69$ & $3.25^{\mathrm{b}}$ & $6.7 \pm 0.2$ & $6.2 \pm 0.1^{\mathrm{e}}$ & $21.5 \pm 4.8^{\text {ef }}$ & $66.0 \pm 2.4^{\mathrm{abc}}$ & $44.4 \pm 4.3^{b}$ & $\mathrm{R}$ \\
\hline
\end{tabular}




\section{Short paper and poster abstracts: $38^{\text {th }}$ Congress of the South African Society of Animal Science}

Average daily gain (ADG) was estimated by fitting a linear model $\left(\mathrm{R}^{2}>0.95\right)$ to live weight data. ADG did not differ significantly between sex types or treatments and is in accordance with the results found by Chadd et al. (1993) and Ellis \& Avery (1994). Feed conversion ratios (FCR) were significantly better for gilts than for castrates, although there appears to be a linear tendency in FCR for the gilts, no significant differences were observed between the different slaughter groups. The $\mathrm{pH}$ measured one hour post mortem was significantly lower for gilts than for castrates $(\mathrm{P} \leq 0.05)$. No significant differences were observed for the different slaughter groups. These values were however, still within the acceptable range and did not indicate the occurrence of the PSE condition. The $\mathrm{pH}$ measured 24 hours post mortem was significantly lower for gilts than for castrates $(\mathrm{P} \leq 0.05)$. The values obtained for castrates indicate the occurrence of DFD pork. Significant differences were also observed for different treatments (Table 1). However, no patterns were observed with the increase in slaughter weight. Both fat thickness and percentage lean meat in the carcass showed significant differences for sex and treatment. In the gilts fat thickness showed a linear increase while the percentage lean meat in the carcass decreased. This decrease was not enough to have a significant influence on carcass classification. These measurements are very similar to those reported by Chadd et al. (1993) for gilts. No tendencies were observed for the castrates and classifications were consistently worse than for the same slaughter group of gilts. Muscle area showed significant differences for sex and treatment as well as sex $\mathrm{x}$ treatment interactions indicating that the rate of change of muscle area was different for the different sex types. The effects of slaughter weight on the economics of pig production under the current classification system versus a classification system neglecting carcass mass is shown in Table 2.

Table 2 Economic implications of producing heavier carcasses under the current classification system

\begin{tabular}{|c|c|c|c|c|c|c|c|}
\hline \multicolumn{8}{|c|}{ Estimated net gain per carcass } \\
\hline & Porcus & Porcus & Sausager & Porcus & Sausager & Porcus & Sausager \\
\hline Liveweight & $90 \mathrm{~kg}$ & $100 \mathrm{~kg}$ & $100 \mathrm{~kg}$ & $110 \mathrm{~kg}$ & $110 \mathrm{~kg}$ & $120 \mathrm{~kg}$ & $120 \mathrm{~kg}$ \\
\hline Price per $\mathrm{kg}(\mathrm{R})$ & 7.25 & 7.25 & 3.72 & 7.25 & 3.72 & 7.25 & 3.72 \\
\hline Cost of producing & & & & & & & \\
\hline a weaner pig $(\mathrm{R})$ & 132.54 & 132.54 & 132.54 & 132.54 & 132.54 & 132.54 & 132.54 \\
\hline Cost of growing pigs (R) & 227.00 & 260.30 & 260.30 & 293.60 & 293.60 & 326.90 & 326.90 \\
\hline $\begin{array}{l}\text { Total cost of producing a } \\
\text { carcass (R) }\end{array}$ & 359.54 & 392.84 & 392.84 & 426.14 & 426.14 & 459.45 & 459.45 \\
\hline $\begin{array}{l}\text { Total income from the sale } \\
\text { of a carcass }(\mathrm{R})\end{array}$ & 450.23 & 500.25 & 256.68 & 550.28 & 282.35 & 600.30 & 308.02 \\
\hline $\begin{array}{l}\text { Net gain from producing } \\
\text { one carcass }(\mathrm{R})\end{array}$ & 90.68 & 107.41 & -136.16 & 124.13 & -143.80 & 140.85 & -151.43 \\
\hline
\end{tabular}

As growth during the period of measurement was linear $\left(\mathrm{R}^{2}>95 \%\right.$, ) the indications are that growth has not peaked and thus that the mature live weight of these animals might have increased due to selection for lean growth. This has various implications for the producer. Gilts should be bred later thus increasing the fixed cost of production. As boar taint is linked to sexual maturity, it might become less of a problem as the mature weight of the animal increases and sex hormones are only secreted at a later age. Thus, a heavier carcass can be produced which is still taint-free, and the growth and carcass characteristics of boars can then be better utilised which will increase the efficiency of pork production and thus the profit margins of producers. Carcass classification did not deteriorate significantly up to $120 \mathrm{~kg}$ live weight. Producers are, however, penalised for carcasses weighing more than $90 \mathrm{~kg}$. This implies that producers are being penalised instead of rewarded for genetic improvement, thus a review of the current classification system is recommended.

\section{Conclusions}

The results presented indicate that modern pig hybrids have the ability to maintain fast growth up to a relatively high slaughter weight without affecting production efficiency or carcass and meat quality characteristics.

\section{Acknowledgements}

Appreciation is expressed to ARC - ANPI and SAMIC for the funding of the project. 


\section{References}

Short paper and poster abstracts: $38^{\text {th }}$ Congress of the South African Society of Animal Science

Chadd, S.A., Cole, D.J.A. \& Walters, J.R., 1993. The food intake, performance and carcass characteristics of two pigs genotypes grown to $120 \mathrm{~kg}$ live weight. Anim. Prod. 57, 473.

Ellis, M. \& Avery, P.J., 1994. The influence of heavy slaughter weights on growth and carcass characteristics of pigs. British Soc. Anim. Prod. 5, 569.

Genstat 5, 1993. GENSTAT 5 committee of the statistical department IACF - Rothamsted U.K., 1995. GENSTAT 5 Reference Manual Clarendon press: Oxford.

Whittemore, C.T., 1993. The science and practice of pig production. Longman, London. 